\title{
SYNCRETIC ARCHITECTURE OF FATEHPUR SIKRI: A SYMBOL OF COMPOSITE CULTURE
}

Asif Ali

\author{
Architecture Section, University Polytechnic \\ Faculty of Engineering and Technology \\ Aligarh Muslim University, Aligarh, India \\ e-mail: asifarchitect@rediffmail.com
}

\begin{abstract}
The amalgamation of native Indians and Muslim immigrants eventuated in a prolific way in the realm of literature, art, music, technology and especially in architecture, which reached at its zenith during Mughal period. Akbar, the great Mughal, is greatly recognized for his syncretism and religious tolerance. With the power of his influential personality and eclectic approach, he unified the various artistic traditions and architectural styles in the design of his new capital city, Fatehpur Sikri. Although, the architectural forms and construction techniques involved in the design of city had already been incorporated since the arrival of Islam in Indian subcontinent, but their synthesis reached at its zenith at Fatehpur Sikri and thus traditionally rich and fanciful indian style was merged with the lightness and simplicity of Islamic style. This paper will focus on the unique intermingling of two entirely different styles like their cultures which were born in different regions and with different approaches. This fusion developed a new style in architecture besides several other aspects of life in India.
\end{abstract}

Keywords: Fatehpur Sikri, Mughal Architecture, Composite Culture, Akbar

\begin{abstract}
Abstrak
Penggabungan India kuno dan imigran muslim menghasilkan banyak literatur, seni, musik, teknologi, dan terutama arsitektur yang mencapai puncaknya selama periode Mughal. Akbar, Mughal yang besar, diakui untuk sinkretisma dan toleransi beragama. Dengan kekuatan pengaruh kepribadiannya dan pendekatan eklektik, dia menyatukan tradisi seni yang bervariasi dan gaya arsitektural pada desain ibukota yang baru, Fatehpur Sikri. Meskipun bentuk arsitektural dan teknik konstruksi terlibat dalam desain kota sudah tergabung sejak kedatangan Islam di India, tapi perpaduannya mencapai puncaknya pada Fatehpur Sikri, jadi gaya India yang fantastis dan kaya secara tradisional digabung dengan kesederhanaan gaya Islam. Artikel ini akan fokus pada pembauran yang unik pada dua gaya yang berbeda seperti budaya yang lahir pada daerah yang berbeda dengan pendekatan yang berbeda. Peleburan ini mengembangkan gaya baru dalam arsitektur di samping beberapa aspek kehidupan yang lain di India.
\end{abstract}

Kata kunci: Fatehpur Sikri, Arsitektur Mughal, Budaya Komposit, Akbar

\section{Introduction}

Babur, who arrived at town Sikri in 1527, changed the name of the town to 'Shukri' which means 'thanks' after the victory over Rana Sanga of Mewar as a symbol of thankfulness ${ }^{1}$, where he built a garden and few buildings. Babur's grandson, Akbar, who moved in the city in $1572^{2}$, renamed the city as Fatehabad $^{3}$ after conquest of Gujarat in 1573 and which in later days came to be known as "Fatehpur Sikri". The strategic location of the new capital of Akbar seems sensible as it offered a gateway to Gujrat, the new expansion of his territory. It was the same village where Shaikh Saleem Chishti's hermitage was stood and Akbar was blessed by a son,
Saleem, by his prayers. The buildings with courtyards and terraces were erected and an artificial lake was dammed over a seasonal river Khari Nadi to fulfill the need of water in the city. The eclectic approach of the great Mughal emperor, his personal involvement in the planning and expertise craftsmen from all over the kingdom made the city marvelous and extraordinary ${ }^{4}$. Shaikh Saleem Chishti, who was not happy with the transformation of his peaceful village to a busy city, one day, said to emperor that either Akbar or he himself would have to leave Sikri. In 1585 (10 Ramzan, 993 A.H.), less than fifteen years after the city was founded, Akbar deserted the city forever due to the paucity of water. However, 
the buildings are still there to narrate the stories of their past dwellers and to portray the social and cultural synthesis as could be experienced through their architectural style.

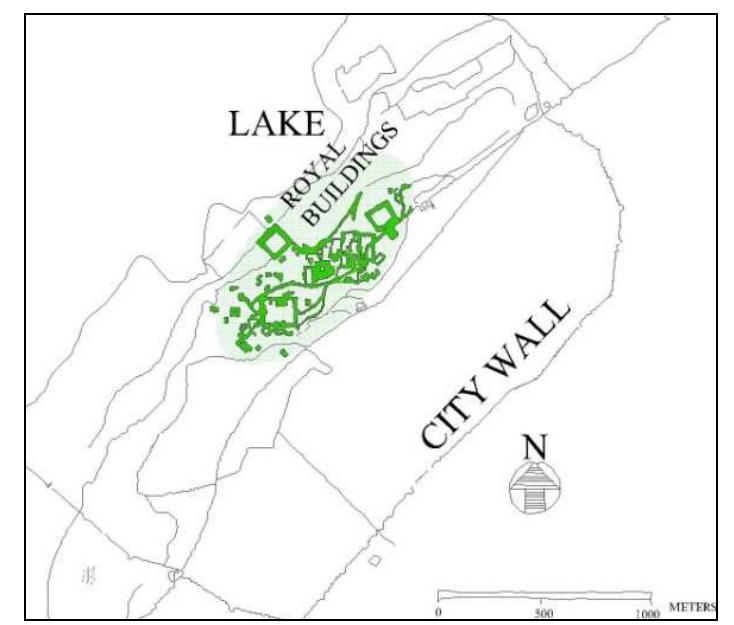

Figure 1. Plan of the City of Fatehpur Sikri

\section{Plan of the City and its Spatial Organization}

On a ridge of red sandstone jutting up from the flat sloped in north easterly direction, the city of Fatehpur Sikri was fortified with the city walls on three sides and a lake on the fourth side as a natural barrier. The city was planned in such a manner that the ridge was kept reserved for the royal buildings for security reasons and the land on the each side was selected for ordinary people (Figure 1).

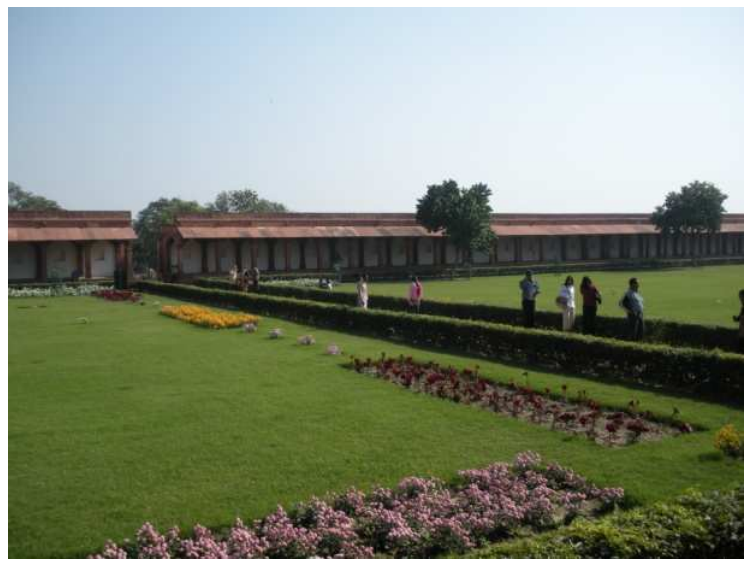

Figure 2. Diwan-i-Aam (Public Court).

The royal buildings are almost at an angle of 45 degrees with the river bed to align them with the strict axis of the mosque towards Qibla, dominating structure of any Islamic city, however, the growth of the city is along the ridge to provide a comparatively flat ground surface. Existing natural level of ground was maintained to make project economical as well as eco friendly. Overall visual unity in the construction was maintained by using red sandstone with white marble. According to Prof. R. Nath, the buildings may be grouped into three different types ${ }^{5}$, viz. (i) Sahn-i-lbadat (The Sacred Complex) that includes religious buildings of the city such as Jami Masjid, Buland Darwaza, tomb of Shaikh Saleem Chishti etc., (ii) Sahne-i-Khas (The Royal Complex) that includes Palaces, Bazars, horse and camel stables etc. and (iii) Sahn-i-Rayyat (The Public Court) that includes Diwan-i-Aam, the imperial workshop, the Aankh Michauli, the Girls' School, Anoop Talao etc.

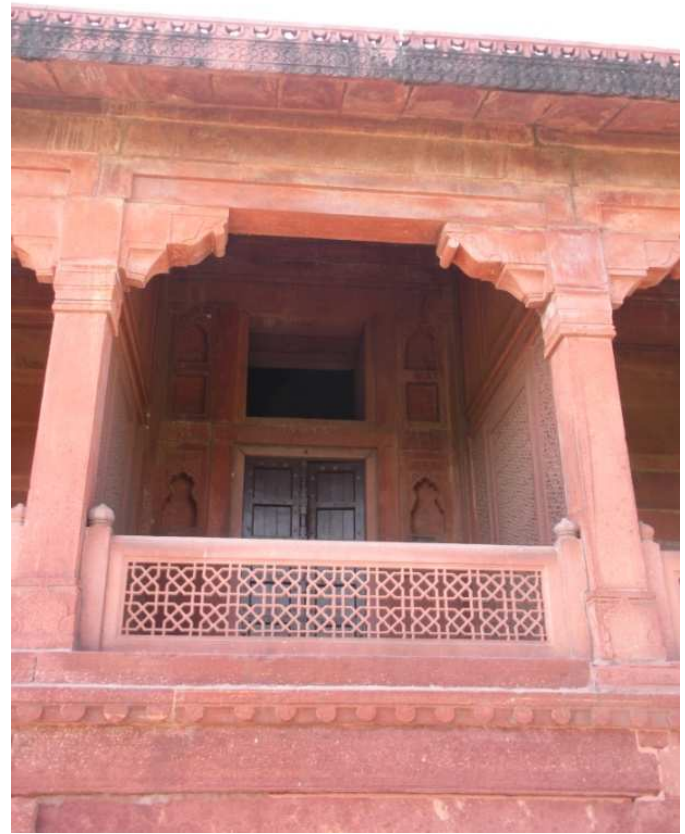

Figure 3. Emperor's Throne Pavilion.

Agra gate, one of the nine gateways to the city is on the north east side, which leads to carvansarai, the bazaar, gardens, royal residences and Tansen Baradari. On the south of the city a square single storey building with central court yard was probably used as a taksal (the mint). Opposite to this building there is a complex of five rooms popularly known as treasury. Diwan-i-Aam (Public Court) consists a central courtyard surrounded by pillared verandah with a throne pavilion on the western side which opens through a back door to the emperor's private apartments (Figure 2 and 3). Akbar used to sit in the pavilion with his officials for Jharokha Darshan, a ceremony of Hindu origin. Akbar's Khwabgah consists of bed rooms, verandahs, pavilions and screen passages (Figure 4). Khwabgah was connected to the harem and Panchmahal through covered passages so that the royal women could move from one area to another without get disturbed their privacy. 


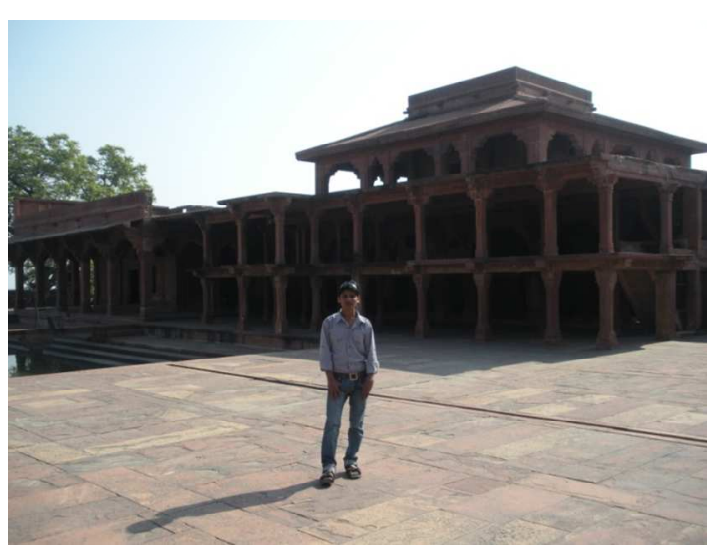

Figure 4. Akbar's Khwabgah.

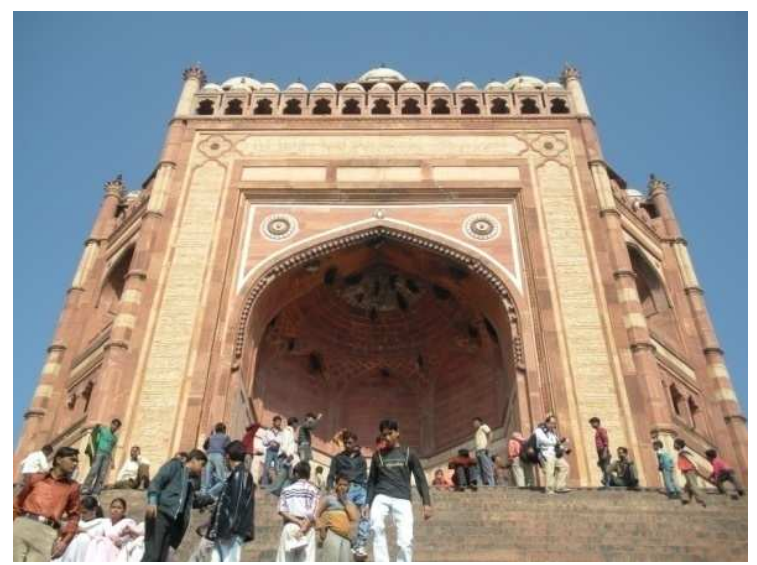

Figure 5. Buland Darwaza.

Jami Masjid is widely appreciated by historians and travelers of that period, even exaggerated as 'second only to the mosque of Mecca' in the Persian inscription placed at its doorway. Badshahi Darwaza, an eastern gate to the mosque was used as a royal entrance. Earlier a small gateway in the southern wall, similar to the eastern gate, was built probably as a public entrance. After Ranthambore victory Akbar decided to build a triumphal gateway by replacing the southern gate of the Jami Masjid called Buland Darwaza (Figure 5). An ablution pool is in the mid of courtyard and tomb of Islam Khan and zenana Rauza (tomb of Shnaikh's family and ladies) are in the north. In contrast to the whole complex in red sandstone a building completely in white marble is located in front of Buland Darwaza is the mausoleum of Shaikh Salim Chishti (Figure 6). Radical change in finishing material from red sandstone of surrounding buildings to white marble marked a question over the attribution of this building. The work seems of a later period, because marble was used frugally during Akbar's reign. It is not impossible that Akbar may had constructed it in red sandstone and later his grandson Shahjahan rebuild it, as he reconstructed many buildings at Agra fort erected by Akbar.

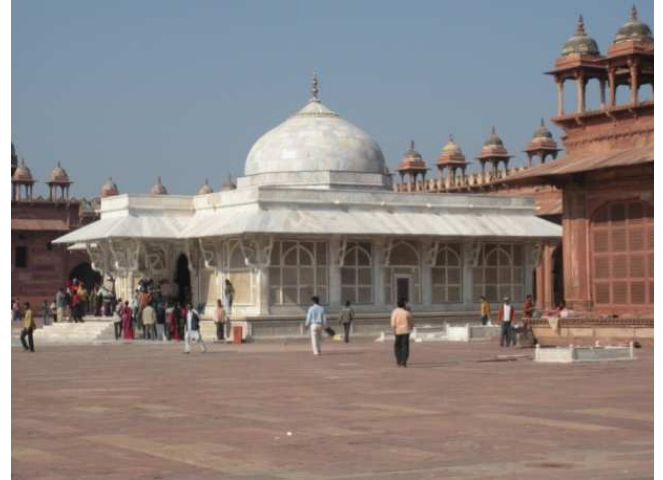

Figure 6.Tomb of Sheikh Saleem Chishti.

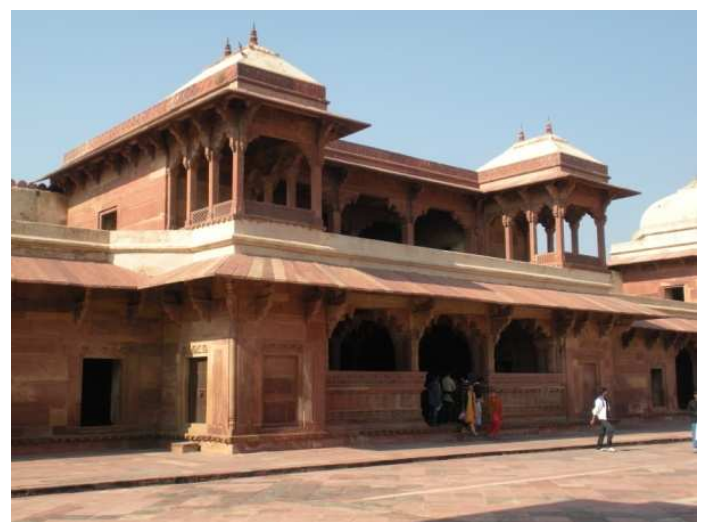

Figure 7.Joda Bai's Mahal.

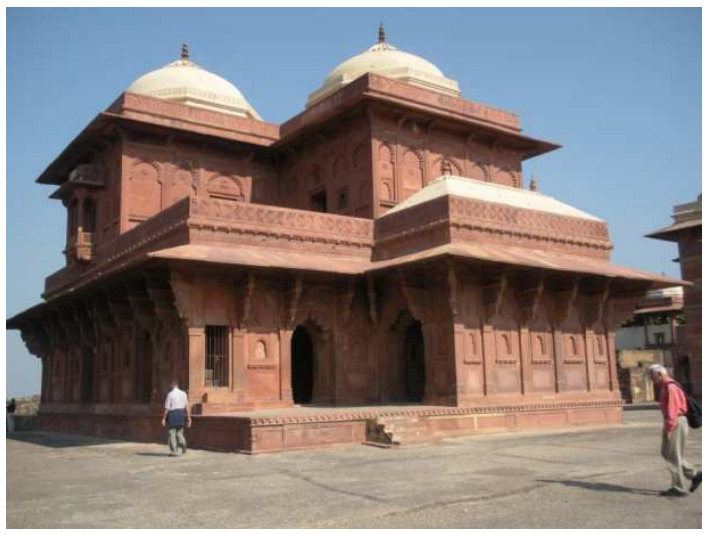

Figure 8.Birbal's house.

On the north east corner of Anup Talao is the house of Turkish Sultaness which is connected to the girl's school which was supposed to be supervised by Turkish Sultaness. On the east of large courtyard is Diwan-i-Khas (Private audience hall), once separated by a wall that has now been demolished. Joda Bai's Mahal, the largest building in the campus, is a traditional courtyard type building which suits best to the climate (Figure 7). Adjacent to Joda Bai's Mahal is so called Birbal's house, a two storey building with four attached rooms on the ground and two on the first floor (Figure 8). Each room on first floor is covered by hemispherical dome resting on an octagonal drum. 


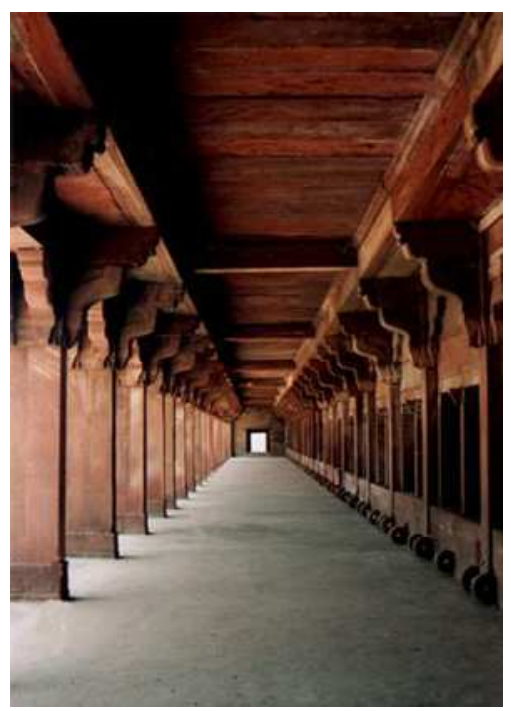

Figure 9. Stable showing Traditional Indian Trabeated System.

\section{Architectural Styles and Building Techniques}

Prof. R. Nath opined that the city of Fatehpur Sikri depicts one of the most original styles of the medieval India in the light of his findings on the main sources of the architectural elements in the construction of the city viz. (i) the Chambal Region, comprising of Delhi, Agra, Fatehpur Sikri, Dholpur and Gwalior and (ii) the Malwa-Gujarat-Rajasthan Region. The locally available material ${ }^{6}$, sandstone, was cut into the shape of lintels, beams, columns brackets and roofing tiles were quickly assembled with or without mortar. Traditional Indian trabeated system was employed for construction but with lightness and simplicity of Islamic style (Figure 9) and thus massiveness and rich decoration of Indian style were avoided in most of the buildings. The arches were used at the façade only for decorative purposes which were not true arches. Jami Masjid is the only building which has an arcuated structural system in contrast to other buildings (Figure 10).

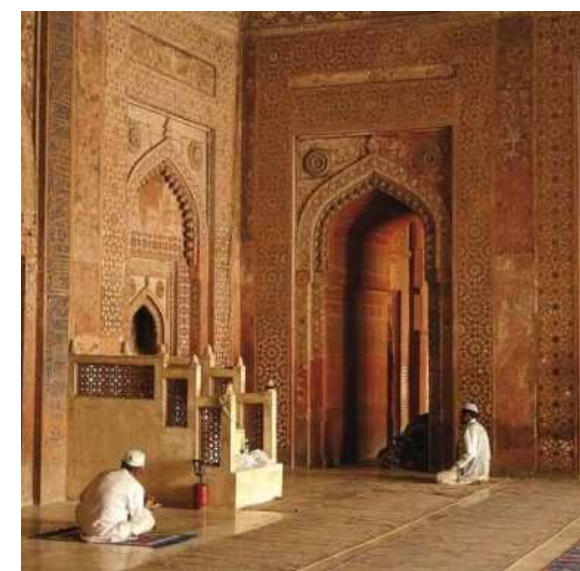

Figure 10. Jami Masjid built in arcuated System.
The oldest structure of Akber's city is the Stone Cutter's mosque on the rock near the site where Shaikh Saleem Chishti's hermitage was located once. It reflects more of Gujarati style, probably built for the artisans involved in building construction of the city $^{7}$. To the south of Aankh Michauli, red sandstone Chhatri with snake like brackets evokes Toranas, a distinct feature of Jain Architecture.

\section{Symmetry and Multiple Axes}

Though the plan of Fatehpur Sikri looks irregular but there is an order in its planning, the plan gives an impression of multiple axes when studied in detail ${ }^{88}$ (Figure 11). Diwan-e Khas and Aankh Michauli are symmetrical about east west axis. Diwan- Khas has a visual relationship with Khwaabgah located on the southern side. Similarly water body near Khwabgah is linked with Maryam's house along its east west axis. The grand building of Buland Darwaza imposes itself as an individual building, not harmonized with the rest of the buildings and even its position is not aligned with the tomb of Shaikh Salim Chishti which is exactly opposite to the gate. The location of Diwan-i-Aam was kept at the entrance by breaking the symmetry due to the security reasons.

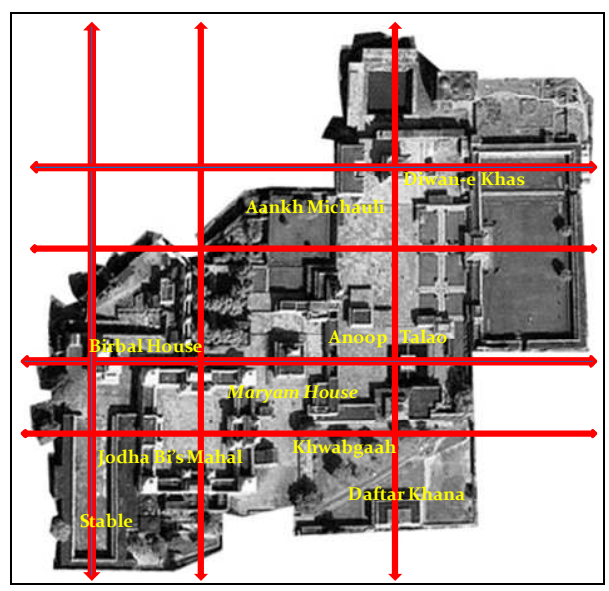

Figure11. Symmetry in Buildings of Fatehpur Sikri about Multiple Axes.

\section{Symbols and Meanings}

Various Hindu motifs have been symbolically used in the buildings, like Padma (lotus flower) at the apex of arch, Kirtimukha on the base of column and Satkona (six pointed star). Anup Talao, a water body with a raised platform in the centre and four pathways converging to it from all sides evokes the Mughal Charbagh (four gardens) symbolises the paradise. The purpose of the building, popularly known as Diwan-i-Khas, is still controversial as it is said that it was used as a private audience hall 
where the Emperor used to sit in the centre and his ministers on the periphery. But the narrow balconies could not allow the ministers to sit comfortably for hours. It seems that the radiating balconies to the central pillar are the symbolic representation of merger of different cults and religions (Figure 12). Figurative representation of two elephants at elephant gate in relief is derived from Rajasthan style gateways where it was a common practice.

\section{Ornamentation and Decoration}

One of the pavilions on the terrace of Akbar's apartment is painted with floral patterns and figurative representation which seems Chitra Shala (Studio), a common feature in royal contemporary Hindu homes. The Birbal house has richly carved interior and exterior with high relief work and the house of the Turkish.

Sultaness is extensively decorated from floor to ceiling with floral and figurative representations and Hindu Swastikas were used for decoration, the work seems of Gujarati artisan. The Joda Bai's Mahal is located on a higher terrain and outer walls are simply decorated with three centered arches with lotus garland along its intradoses. The interior of Diwan-e-Khas has a richly carved pillar at the centre with 36 brackets on which a circular stone platform is resting it is certainly a Gujarati artisans' work (Figure 13). Four Chhatris, surmounted by Mahapadma (lotus) and Kalasha (Pitcher) at the corners of the Diwan-e-Khas were traditional crowning elements of Indian temples.

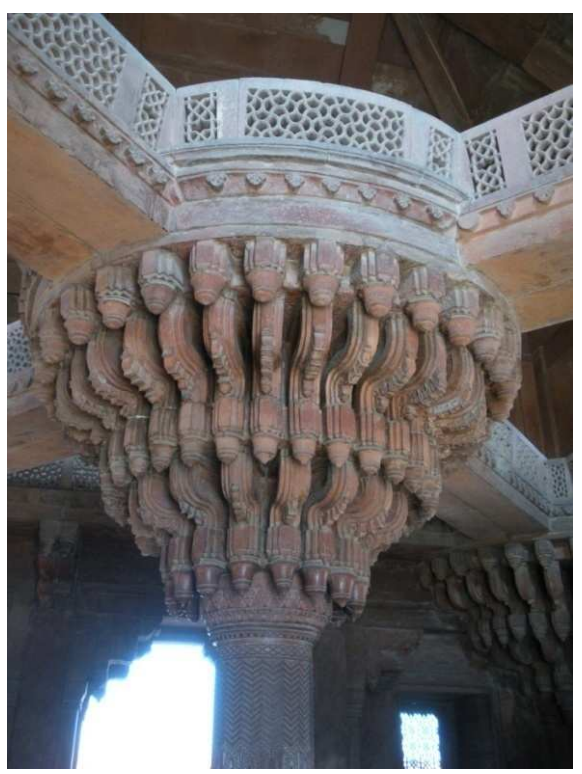

Figure 12. Radiating Balconies Symbolising the Merger of Different Religions.

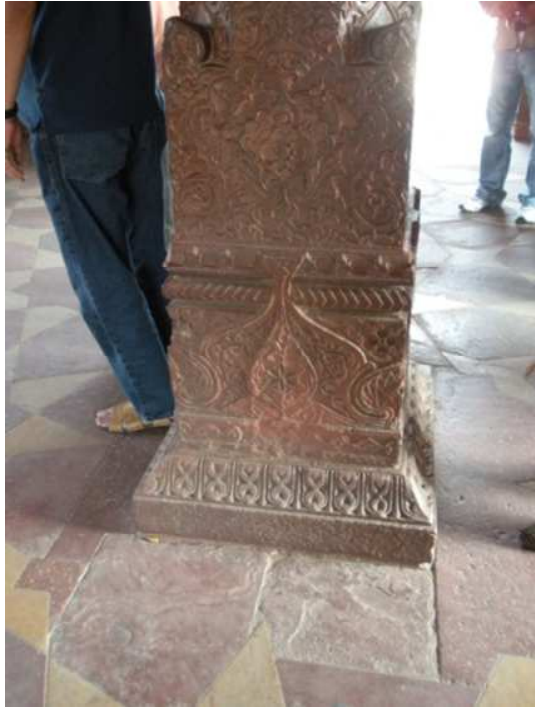

Figure 13. Richly Decorated Pillar in the Gujrati Style.

\section{Conclusion}

The syncretic architecture of Fatehpur Sikri is not simply a synthesis of various styles but also a cultural legacy of the region and artisans of that time. The architectural vocabulary used in the design may have been derived or imitated from different sources, variant in functions, diverse in contexts, varied in precedents but their amalgamation at Fatehpur Sikri is remarkable. Moreover, it represents a composite culture of India despite of different faiths, rituals, customs and ethos in the country.

\section{Reference}

1 Binaca Maria Alfieri. 2000. Islamic Architecture of Indian Subcontinent. London: Laurence King Publishing.

2 R. Nath. 2010. Architecture in Medieval IndiaForms, Context, Histories. Monica Juneja (Editor). New Delhi: Orient Blackswan.

3 http://en.wikipedia.org/wiki/Fatehpur_Sikri

4 Satish Grover. 2002. Islamic Architecture in India. New Delhi: CBS Publishers and Distributers. South Asia Books; 1st edition 1996.

5 Ram Nath. 1987. Fatehpur Sikri. Michael Brand and Glenn D. Lowry [Editor]. Bombay: Marg Publication.

6 Catherine B. Ashar. 2008. The New Cambridge History of India-Architecture of Mughal India. Cambridge: Cambridge University Press.

$7 \quad$ Percy Brown. 1997. Indian Architecture (Islamic Period). Mumbai: D. B. Taraporewala.

8 Attilio Pettruccioli. 1987. Fatehpur Sikkri. Michael Brand and Glenn D. Lowry [Editor]. Bombay: Marg Publications. 